International Journal of Heritage, Tourism and Hospitality Vol. (13), No. (1), March, 2019

By: Faculty of Tourism and Hotels, Fayoum University

\title{
Egypt's Travel and Tourism Competitiveness Index In Comparison to Competitive Tourism Destinations In The Middle East And North Africa Region:
}

\author{
I. Rouby \\ Faculty of Tourism and Hotels, Alexandria University
}

\begin{abstract}
Nowadays tourism has become one the most important industries in the global economy. It has succeeded to support many economies and has been considered a remarkable generator of direct and indirect job opportunities. Therefore, many countries are trying to increase their competitiveness in order to attract tourists and satisfy their needs. Competitiveness is rather a relative concept depending on the variables in question. Many competitiveness models emerged during the last decades. Some of these modelsfocused on the resources, climate, geography of the destinations, while others focused on the level of sustainability adoption and others regarded prices as the major factor affecting competitiveness.

This study aims at evaluating the competitiveness of the Travel and Tourism (T\&T) sector in Egypt versus some competitive destinations in the MENA (Middle East and North Africa) region. The analysis was based on the secondary data provided by the Travel and Tourism Competitiveness Report of 2017 issued by the World economic Forum.The report identified some important sub-indexes such as enabling environment, infrastructure, T\&T policies and enabling conditions, cultural and natural resources as indicators for T\&T competitiveness.

In order to answer the research questions, Pearson's correlation was conducted to assess the strength and direction of relationship between the overall T\&T competitiveness index and other sub-indexes. A PESTEL analysis was also conducted to examine whether Egypt has the potentials to enhance its competitive position worldwide if effective destination management policies were applied.

The analysis showed that the chosen countries differentiate to a certain extent in some indicators while they share others. As Bahrain and Saudi Arabia are heading others in the pillars related to "Labor market and human resources" and "ICT readiness", "T\&T prioritization" is highly ranked in Jordan, Egypt and Morocco compared to others. Nevertheless, all countries share a drawback in pillar "International openness".

Pearson's correlation showed that pillars "Business environment", "Air transport infrastructure" and "ICT readiness" have a stronger positive relationship to the variable overall T\&T competitiveness index compared to other variables. The PESTEL analysis revealed that Egypt has the potentials and resources that can support it to enhance its competitiveness in the region. These potentials include "Price competitiveness", "Prioritization of T\&T" by the government, "Cultural and natural resources" in addition to "Air infrastructure". These strengths have to be sustained by government policies and weaknesses like political instabilities should be effectively restrained in order to improve Egypt's competitiveness worldwide.
\end{abstract}

Keywords: Egypt, Competitiveness, MENA, PESTEL, Pearson's Correlation, Sub-index, TTCI

\section{Introduction}

The tourism industry supplied the global economy with US\$7.6 trillion in 2016, accounting for $10 \%$ of the global GDP while recording 1.2 billion international arrivals and contributing with292 million jobs. In 2017, it continued to show an increasing yearly growth rate since 2012 and surpassing global economic growth. The tourism industry managed to face global economic and political instabilities and continued to provide many countries with jobs, growth and economic development. The industry constitutes a strong employment generator, creating a new 
job for every new tourist and accounting for $30 \%$ of the global services sector (T\&T Competitiveness Report, 2017).

These figures indicate that this industry has to be strongly supported by many countries especially by some developing countries, where their balance of payment is covered to a great extent by the tourism income and tourism is considered a key element for economic growth. In order to guarantee benefits generated by the tourism sector, destinations should remove barriers that could prevent the industry growth while taking into account nurturing sustainability issues. Furthermore, it is worth to mention, that in order to increase competitiveness, governments should enhance business environment, regulatory frameworks and develop infrastructure through well-planned policies and effective destination management strategies.

This research tends to explore the position of Egypt as a tourist destination among its competitors in the MENA region. This region has been suffering in the last decades from political instabilities and recently the effects of the Arab Spring. These circumstances have had major effects on the region in general and the tourism industry in specific. Some countries were greatly affected by the events while others weren't significantly influenced. All the Arab tourism destinations are now trying to design policies to counteract the effects of the political chaos and are taking serious steps to get back the tourism flow.

This study aims to answer the following research questions:

Q1: Do some sub-indexes of the T\&T Competitiveness index (TTCI) play a stronger role than others to enhance the ranking of the country?

Q2: Does Egypt have the potential to raise its TTCI?

The study has employed the descriptive-analytical research approach to answer research questions and find relationships between study variables. Pearson's correlation was conducted to examine the level and direction of the relationship between the overall TTCI and certain subindexes. Furthermore, a PESTEL analysis was conducted to assess whether Egypt has the potential to raise its competitiveness position worldwide.

The following part reviews the different concepts of competitiveness and presents some models that were designed by academics to measure competitiveness among destinations. Successively, the methodology of research will be presented, which is in its first part descriptive in nature, where the TTCI of some chosen countries in the MENA region were compared and analytical in its second part to identify relationships between variables.

\section{The Concept of Competitiveness and its Models}

The competitiveness of a tourism destination is rather a complicated and relative concept. This is due to the fact, that every destination has its own history, traditions, cultural and natural resources, different objectives, special strategies, diverse levels of embracing technology and diverse approaches to sustainability adoption.

Obviously, there is an intense competition between countries worldwide to attract tourists. Competitiveness has become essential for destinations in order to survive in the global market and gain a respectable share. Each destination tends to reach the utmost benefit from its tourism assets to satisfy customer needs and enhance customer experience. This can be accomplished by identifying firstly tourists' motivations for travelling and factors affecting consumer choice.

Buhalis (2000:12) defines competitiveness as "the effort and achievement of long-term profitability, above the average of the particular industry within which they operate as well as above alternative investment opportunities in other industries". 
According to Hassan (2000:239-240), competitiveness is concerned with "the destination's ability to create and integrate value-added products that sustain its resources while maintaining market position relative to competitors". Dwyer and Kim (2003:374) state that destination competitiveness is "the ability of a destination to deliver goods and services that perform better than other destinations on those aspects of the tourism experience considered being important by tourists". Crouch and Richie (2003) describe competitiveness as the capability of a destination to attract visitors and give them unforgettable experiences while enhancing the welfare of the community and at the same time protecting the natural environment for next generations. All of this has to be done in a profitable way for the destination by encouraging tourist expenditure. Authors have approached the concept of competitiveness differently and from diverse aspects. They have adopted several models to measure competitiveness of destinations. Some authors have addressed it by assigning to it quantitative variables, such as tourist arrivals, value added of T\&T sector, tourist expenditures, employment, or qualitative variables, such as wealth of culture and heritage and quality of tourism services(Omerzel, 2006).

One of these models is Porters' five forces framework, which takes into account several macroand microeconomic factors affecting the organization and structuring its business environment. The five forces are:"the threat of substitute products or services, the threat of established rivals, the threat of new entrants, the bargaining power of suppliers and the bargaining power of customers" (Claver-Cortes et al., 2007)

Price competitiveness can play a major role in determining tourism competitive advantage according to Craigwell (2007). Zhang and Jensen (2007) added to price competitiveness natural resources, geography, climate and cultural heritage in order to justify tourism traffic towards a country. Consumers' points-of-view are also essential in the assessment of the competitiveness of tourism destinations. Money, time and effort, experiences, fun, relaxation and memories are among the elements to be considered in this respect (Kotler et al., 2006).

Tourism destinations can increase competitiveness by adopting sustainable tourism principles. Sincere efforts in the area of environmental quality management can increase tourism competitiveness of a destination Mihalič (2000). Hassan's model (2000) also highlighted the importance of environmental sustainability, as one of the four determinants of tourism competitiveness.

According to (Boo et al., 2009), branding plays also an essential role in enhancing destination competitiveness. Ejarque (2005) proposed the following set of elements to be considered in analyzing the tourist destinations: the geographical location, environmental and physical conditions, demographical situation, existing tourist attractions, image perceived (Royo-Vela, 2009) and image associated with the tourist destination and tourism resources (natural, cultural, activities, infrastructure and services).Cracolici et al. (2008) used a set of six factors to determine the competitiveness of tourism destinations: natural and cultural resources, amount and quality of accommodation and restaurants, accessibility to transportation system, all the activities available at the destination, tourist safety, and local resident conduct.

The model of Crouch and Ritchie (2003) consists of 36 attributes consisting of 5 main factors. The main factors consisted of core resources and attractors, supporting factors and resources, destination policy, planning and development, destination management and qualifiers and amplifiers. The model explains that a country consists of comparative advantages which are natural and man- made resources and competitive advantages, which is how efficiently a country manages its resources. Together the country's comparative advantages added to its competitive 
advantages in tourism create a country's overall ability to compete in the tourism marketplace. These factors are influenced by global macro- and competitive micro-economic factors.

The model of De Keyser and Vanhove (1994) uses macroeconomic factors influencing tourism industry in addition to other factors. According to their model, there are five factors that affect the competitiveness of the destination. These are: tourism policy, macroeconomics, supply, transportation and demand factor. The model was used to analyze the competitiveness of eight Caribbean islands and the results showed that the chief elements of destination appeal are crucial for destination comparative advantage and can be a driving force for tourists' visits. Culture and history, activities and events are examples of those resources attracting tourists.

Kozak and Rimmington (1999) explained that the competitiveness of tourist destinations is based on a combination of two essential factors: (i) primary factors, such as climate, ecology, culture, architectural heritage, and (ii) specific factors of the tourist sector, such as hotels, transport means and entertainment.The OECD set some indicators to address the concept of competitiveness in tourism. These factors are categorized in four distinctive groups: Factors measuring the tourism performance and impacts; Factors for monitoring the capability of a destination to convey quality and competitive tourism services; Factors for monitoring the attraction of a destination and Factors dealing with policy responses and economic prospects (Dupeyras and MacCallum, 2013). In view of the diverse competitiveness evaluation models it became clear that the phenomenon of destination competitiveness is multidimensional where its measurement depends on the choice of the variables being analyzed and research approach in question.

\section{Sub- indexes and Pillars of the T\&T Competitiveness Index (TTCI):}

The TTCI is structured into four sub-indexes, 14 pillars, and 90 individual indicators. The subindexes of the Index are as follows: (1) The Enabling Environment sub-index; (2) The T\&T Policy and Enabling Conditions sub-index (3) The Infrastructure sub-index and (4) The Natural and Cultural Resources sub-index.Each of these sub-indexes is built up by a number of pillars of T\&T competitiveness which are in turn divided into indicators (Fig. 1)(T\&T Competitiveness Report, 2017). These indexes can be used by tourism stakeholders and policy makers of the tourism destinations to assess their destination competitiveness in comparison to other competitive destinations and hereby find solutions to enhance their competitive capabilities to attract more tourists.

Figure 1: The T\&T competitiveness Index 2017 framework

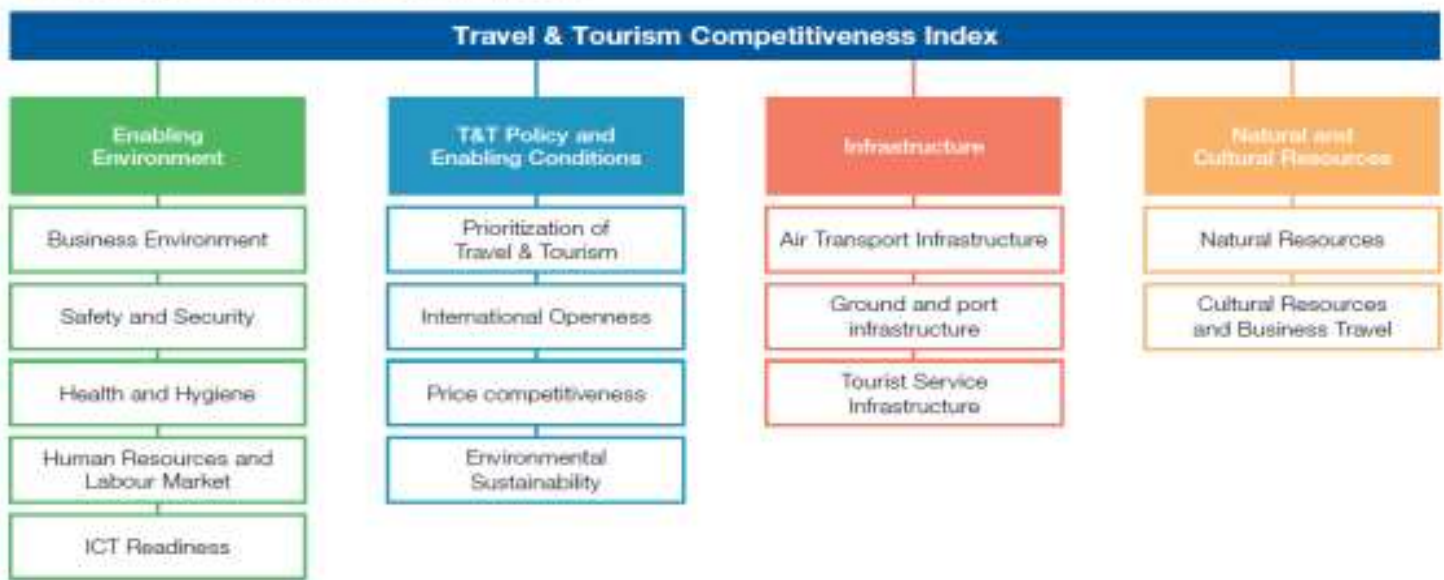

Source: T\&T Competitiveness Report, 2017 
According to the T\&T Report, the Middle East and North Africa has improved its competitiveness in ICT infrastructure, in addition to some enhancements in international openness and cultural heritage.Nevertheless, many natural and cultural resources remain untapped. Security issues remain the biggest impediment for most countries in the region hindering future growth. It can be noticed, that the region has several inconsistencies regarding T\&T indexes. For example, United Arab Emirates and Oman rank high concerning security issues while Yemen and Lebanon rank low concerning thispillar. Some countries have a safe business environment, perform well in ICT and have developed infrastructure like UAE, Bahrain and Saudi Arabia while other countries are ranked low in the same areas.

Some countries have moved faster to enhance their position in certain areas such as Egypt and Oman which upgraded their cultural position considerably if compared to other countries in the region. Others focused on other issues like Bahrain and Tunisia, which progressed in factors determining international openness.

As discussed earlier, there are different methodologies to tackle competitiveness. This research will assess the position of Egypt in comparison to some neighboring countries in the region based ongeographical location combined with the model of Zhang and Jensen (2007) which based competitiveness on price, natural resources, geography, climate and cultural heritage. This purposive sampling techniqueidentifiedJordan, Bahrain, Saudi Arabia, Oman, Lebanon, Tunisia and Morocco as direct competitors to Egypt. This choice was based on the proximity of the TTCI ranking of these candidates to Egypt $\left(74^{\text {th }}\right)$ and also the resemblance in areas such as natural resources, geography, language, climate and cultural heritage.

\section{Methodology of Research:}

The following part is a descriptive analysis of Egypt's ranking compared to other competitive countries in the region.

Egypt's ranking enhanced since 2015 by 9 levels to reach $\operatorname{rank}\left(74^{\text {th }}\right)$ in 2017 . The main factors that drove Egypt's growth were the support of the government to the T\&T sector ( $37^{\text {th }}$ up to 32 places) and the strengthening of "Cultural resources" (22nd, up 19 places). These policies have encouraged the growth in tourism arrivals to reach 9 million tourists after a huge decline in tourism figures after the Arab spring but still short in 5 million than the peak in 2010. One of the major advantages in Egypt is its "Price competitiveness" ranking $2^{\text {nd }}$ worldwide. The country is making solid steps to build its "Air transport infrastructure" $\left(59^{\text {th }}\right)$. Furthermore, the country is ranked $22^{\text {nd }}$ concerning "Cultural resources and business travel'. Still, security issues have to be resolved as it is ranked $130^{\text {th }}$ worldwide with terrorism considered as a destabilizing force. The government has designed definite policies to fight terrorism and increase security which will definitely support growth of the T\&T industry in the future.

Jordan which is ranked $75^{\text {th }}$ has made considerable improvements in many areas. It has made wide leaps to improve "ICT readiness"(44th, up 21 places) by enhancing the usage of mobile technologies. It also managed to keep a high level of security ranking $38^{\text {th }}$ globally which made the country able to maintain constant tourist arrivals for the past four years without being affected by the regions instabilities. The government has also taken steady steps for "T\&T prioritization" $\left(22^{\text {nd }}\right)$ and enhanced its "Business environment" through low administrative burdens to have construction permits and well-protected property rights. Nevertheless, the country has to improve its "Price competitiveness" ranked $\left(81^{\text {st }}\right)$ globally and "Environmental 
sustainability" (82th) and support its "Natural and cultural resources" (117th and 118th, respectively).

Bahrain ranking $\left(60^{\text {th }}\right)$ has a very stable global "Ground and port infrastructure" ranking $\left(13^{\text {th }}\right.$ in addition to a high quality "Tourist service infrastructure" ranking $35^{\text {th }}$. Bahrain has a high "Price competitiveness" ranking worldwide $\left(21^{\text {st }}\right.$ and a high ICT position $\left(16^{\text {th }}\right)$ supported by a high ranking in aspects concerned with "mobile-cellular telephone subscriptions" $\left(4^{\text {th }}\right)$, "mobilebroadband subscriptions" $\left(4^{\text {th }}\right)$ and "internet users" $\left(5^{\text {th }}\right)$. The "Business environment" is also very suitable for investors ranking $\left(12^{\text {th }}\right)$ with a high ranking in indicators related to "effect of taxation on incentives to work" $\left(7^{\text {th }}\right)$ and "effect of taxation on incentives to invest" $\left(2^{\text {nd }}\right)$. However, "Natural and cultural resources" have to be expanded in order to attract more visitors. The pillar "Prioritization of T\&T" $\left(80^{\text {th }}\right)$ has to be given more attention, where the "T\&T data has to be carefully comprehended" supported with major adjustments in "T\&T government expenditure" $\left(50^{\text {th }}\right)$. Also "Environmental sustainability" must be considerably enhanced.

Tunisia has dropped 8 places to take the $87^{\text {th }}$ position in 2017 index. Its "Price competitiveness" is strong $\left(9^{\text {th }}\right)$ with also a powerful support of the government for the T\&T sector $\left(48^{\text {th }}\right)$. Concerning "Business environment", Tunisia has focused on some factors like "time to get construction permits" but more emphasize should be puton indicator concerned with "total tax rate". Nevertheless, the country should focus on enhancing "Security and safety" measurements $\left(102^{\text {nd }}\right)$ which constitute a main constraint to tourism growth in the country. Also, "Natural and cultural resources" aren't sufficiently tapped and under-valued. Furthermore, "Ground and port infrastructure" has to be enhanced $\left(95^{\text {th }}\right)$ especially concerning indicators such as "road density", "quality of port infrastructure" and "ground transport efficiency". The pillar "Environmental sustainability" $\left(89^{\text {th }}\right)$, which constitutes a global focus isn't adequately supported by the country. International tourist arrivals were also affected by low quality of "Air infrastructure". The whole industry has to be restructured and security issues resolved in order to stabilize T\&T growth rates.

Oman is ranked $66^{\text {th }}$ in the T\&T report with one position less than 2015 . Oman has a very high ranking related to pillar "Safety and security" $\left(4^{\text {th }}\right)$ and ranking $\left(1^{\text {st }}\right)$ in the indicator "terrorism incidence" which is considered unique to the region. It has a moderate ranking related to "Price competitiveness" $\left(24^{\text {th }}\right)$ and "Business environment" $\left(28^{\text {th }}\right)$ (Table 1$)$. Some efforts have to be done concerning pillar "International openness" $\left(116^{\text {th }}\right)$ especially related to indicators such as "visa requirements" $\left(112^{\text {th }}\right)$ and "openness of bilateral Air Service Agreements" (102th). In addition, the government should support the "Prioritization of T\&T" $\left(116^{\text {th }}\right)$ by increasing for example government spending to insure tourism growth. More developments should be done to air, ground and tourist infrastructure to satisfy the needs of tourists and improve their travel experience. Furthermore, natural resources aren't fully tapped and cultural resources have to be enhanced concerning indicators such as "protected areas" and "world heritage sites list" as Oman has no attraction on the list. The "ICT readiness" ranking is $46^{\text {th }}$ with rank $14^{\text {th }}$ regarding the indicator "mobile-cellular telephone subscriptions". The country should make more efforts concerning pillar "Labor market" with ranking $\left(103^{\text {rd }}\right)$ especially with indictors related to "hiring and firing practices" $\left(117^{\text {th }}\right)$ and "ease of finding skilled employees" $\left(118^{\text {th }}\right)$. 
International Journal of Heritage, Tourism and Hospitality Vol. (13), No. (1), March, 2019

By: Faculty of Tourism and Hotels, Fayoum University

Table 1: Business environment sub-indexes for Oman

\begin{tabular}{lrrr|}
\hline Index Component & Rank/136 & Score $^{x}$ \\
\hline BusIness envlronment & 28 & 5.1 \\
\hline Property rights & 28 & 5.4 \\
\hline Business impact of rules on FDI & 100 & 4.1 \\
\hline Efficiency of legal framework in settling disputes & 31 & 4.6 \\
\hline Efficiency of legal framework in challenging regs & 37 & 4.1 \\
\hline Time required to deal with construction permits days & 80 & 157 \\
\hline Cost to deal with construction permits \% construction cost & 46 & 1.1 \\
\hline Extent of market dominance & 108 & 3.2 \\
\hline Time to start a business days & 29 & 6.0 \\
\hline Cost to start a business \% GNI per capita & 51 & 4.0 \\
\hline Effect of taxation on incentives to work & 6 & 5.3 \\
\hline Effect of taxation on incentives to invest & 9 & 5.2 \\
\hline Total tax rate \% profits & 21 & 23.9 \\
\hline
\end{tabular}

Source: T\&T Competitiveness Report, 2017

Saudi Arabia is ranked63 $3^{\text {rd }}$ with one position up compared to 2015 . The country is ranked $27^{\text {th }}$ concerning pillar "ICT readiness" ranking $6^{\text {th }}$ in the indicator"mobile-cellular telephone subscriptions". The country is also highly ranked in pillars such as"Price competitiveness" $\left(17^{\text {th }}\right)$ and "Qualityof tourist infrastructure" $\left(38^{\text {th }}\right)$ offering sufficient air connectivity. Nevertheless, the country should pay more attention to pillars such as "Natural resources" $\left(99^{\mathrm{th}}\right)$, "Prioritization of T\&T sector" ( $\left.83^{\text {rd }}\right)$ and "International openness" $\left(131^{\text {st }}\right)$. It is worth to mention, that Saudi Arabia has a unique position concerning the $\mathrm{T} \& \mathrm{~T}$ sector, as it has a constant tourism flowfrom religious tourism related to Hij and Ommra. Should the country decide to tackle new tourism genre, it should initiate policies that target a different kind of tourist.

Morocco is ranked $65^{\text {th }}$ with three positions down compared to 2015 . The country is ranked $20^{\text {th }}$ globally concerning "Security and safety" which indicates that the country was not much affected by the political instability in the region reflected by the Arab Spring. Morocco has a fair flexible "Business environment" substantiated by initiatives by the government to prioritize the tourism sector $\left(35^{\text {th }}\right)$. Nevertheless, great efforts should be done to enhance pillars such as "Labor markets and human resources" $\left(117^{\text {th }}\right)$ especially in areas like "secondary education enrollment rate" $\left(103^{\text {rd }}\right)$, "extent of staff training" $\left(124^{\text {th }}\right)$, "hiring and firing practices" $\left(100^{\text {th }}\right)$ and "Female participation in the labor force" $\left(130^{\text {th }}\right)$. Also, the government should seek to enhance pillars like "International openness" $\left(91^{\text {st }}\right)$ and "Environmental sustainability" $\left(107^{\text {th }}\right)$. The country is rich in cultural and natural resources with 9 world heritage cultural sites. More attention should be paid to upgrade air and ground infrastructure to attract more tourists $\left(80^{\text {th }}, 63^{\text {rd }}\right.$ and $60^{\text {th }}$ respectively).

Lebanon, although ranked $96^{\text {th }}$ globally with major shortcomings in many areas related to T\&T competitiveness, it managed to rank second among the chosen candidates of the research related to tourism receipts. It has a fair" Price competitiveness" $\left(27^{\text {th }}\right)$ and the government focuses on the development of the tourism sector as it supports $8.1 \%$ of its GDP. Major enhancements should be tackling a rigid "Business environment" $\left(95^{\text {th }}\right)$ which is a major deterrent to investments and where the problem is furtherintensifiedby an ineffective "Labor market" $\left(120^{\text {th }}\right)$. "Safety and security" constitute a major drawback to its competitiveness ranking $\left(125^{\text {th }}\right)$ with a low value preposition of the natural resources $\left(128^{\text {th }}\right)$. Major developments should be directed to air and ground infrastructure which are main drivers of the tourism demand. The country should pay 
more attention to the main issue of international concern, namely environmental sustainability with rank $\left(110^{\text {th }}\right)$ especially in indicators such as "stringency of environmental regulations" $\left(135^{\text {th }}\right)$, “enforcement of environmental regulations" $\left(134^{\text {th }}\right)$ and "Sustainability of travel and tourism industry development" $\left(105^{\text {th }}\right)$.

Table 2: TTCI of Middle East and North Africa countries

\begin{tabular}{|c|c|c|c|c|c|c|c|c|c|c|c|c|c|c|c|c|}
\hline 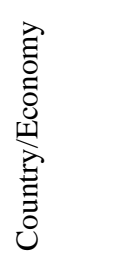 & $\vec{U}$ & 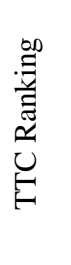 & 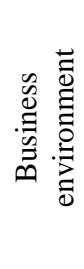 & 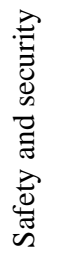 & 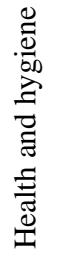 & 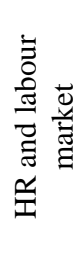 & 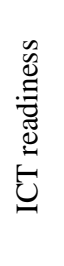 & 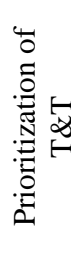 & 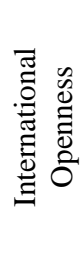 & 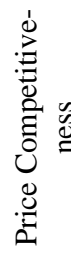 & 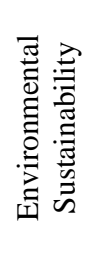 & 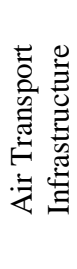 & 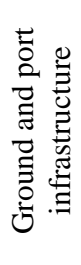 & 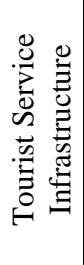 & 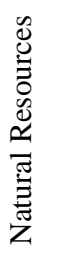 & 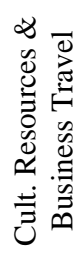 \\
\hline UAE & 4.49 & 29 & 5.9 & 6.6 & 5.4 & 5.2 & 6.1 & 5.1 & 3 & 5 & 4.5 & 5.8 & 4.9 & 5.4 & 2.6 & 2.2 \\
\hline Qatar & 4.08 & 47 & 5.8 & 6.3 & 6 & 5.2 & 5.8 & 4.5 & 2 & 5.7 & 4.1 & 4.3 & 4.7 & 5 & 1.8 & 1.6 \\
\hline Bahrain & 3.89 & 60 & 5.5 & 5.7 & 5.2 & 4.7 & 6 & 4.3 & 2.9 & 5.5 & 3.8 & 3.5 & 5.2 & 4.9 & 1.7 & 1.3 \\
\hline Israel & 3.84 & 61 & 5 & 4.6 & 6.1 & 5.2 & 5.5 & 4.6 & 2.5 & 3.1 & 3.9 & 3.2 & 4.2 & 5.4 & 2.6 & 2 \\
\hline $\begin{array}{l}\text { Saudi } \\
\text { Arabia }\end{array}$ & 3.82 & 63 & 5.2 & 5.5 & 5.6 & 4.6 & 5.6 & 4.4 & 1.6 & 5.6 & 3.5 & 3.7 & 3.3 & 4.7 & 2.5 & 2.2 \\
\hline Oman & 3.78 & 66 & 5.1 & 6.5 & 5.4 & 4.1 & 5.1 & 4.4 & 2.2 & 5.5 & 3.7 & 3 & 3.9 & 4.1 & 2.6 & 1.9 \\
\hline Jordan & 3.63 & 75 & 4.8 & 5.8 & 5.5 & 4.5 & 5.1 & 5.3 & 3.3 & 4.8 & 4 & 2.6 & 3 & 4.1 & 2.3 & 1.3 \\
\hline Iran. & 3.43 & 93 & 4.3 & 5.2 & 4.7 & 4.1 & 3.8 & 3.6 & 2.4 & 6.7 & 3.6 & 2.2 & 3.1 & 2.5 & 2.4 & 2.8 \\
\hline Lebanon & 3.37 & 96 & 4.2 & 3.6 & 5.9 & 3.8 & 4.3 & 5 & 2.5 & 5.5 & 3.7 & 2.4 & 2.9 & 4.3 & 2.1 & 1.4 \\
\hline Kuwait & 3.33 & 100 & 4.6 & 5.7 & 5.4 & 4.3 & 5.5 & 3.3 & 1.9 & 5.3 & 3.1 & 2.5 & 3.5 & 3.8 & 1.9 & 1.2 \\
\hline Yemen & 2.44 & 136 & 3.5 & 2.8 & 3.8 & 3.2 & 2.3 & 2.4 & 1.3 & 5.9 & 2.8 & 1.5 & 2 & 2.2 & 1.9 & 1.3 \\
\hline Morocco & 3.81 & 65 & 4.7 & 6.1 & 4.6 & 3.9 & 4.3 & 5 & 2.7 & 5.2 & 3.7 & 2.8 & 3.4 & 3.8 & 3.6 & 2.5 \\
\hline Egypt & 3.64 & 74 & 4.3 & 3.3 & 5.4 & 4.1 & 3.9 & 5 & 2.5 & 6.2 & 4.1 & 2.9 & 3 & 3.2 & 2.5 & 3.3 \\
\hline Tunisia & 3.5 & 87 & 4.4 & 4.7 & 5.2 & 4 & 4.3 & 4.8 & 3 & 5.9 & 3.9 & 2.3 & 2.7 & 4.1 & 2.5 & 1.5 \\
\hline Algeria & 3.07 & 118 & 4 & 5.3 & 4.9 & 4 & 3.7 & 2.8 & 1.5 & 6 & 3.7 & 2.1 & 2.5 & 2.1 & 2.2 & 2.1 \\
\hline
\end{tabular}

Source: T\&T Competitiveness Report, 2017 
Table 2 presents the TTCI and the indexes of the sub-indexes of the Middle East and North Africa countries. Bahrain ranks first among the chosen countries concerning effectiveness of "Business environment" followed by Saudi Arabia. Oman ranks first in the area of "Safety and security" followed by Morocco. Lebanon and Saudi Arabia precede the rest of the countries in "Health and hygiene". In the pillars relatedto"Labor market and human resources" and "ICT readiness", Bahrain and Saudi Arabia are heading others. Considering the T\&T as a priority sector is highly ranked in Jordan followed by Egypt and Morocco. The area of "International openness" is a drawback in almost all of the chosen countries with low indexes. Major leaps have to be done in this area to facilitate tourism flow.

Egypt ranks first among the chosen countries in the area of price competitiveness followed by Saudi Arabia. It is worth to mention, that all of the chosen candidates have to take serious measures concerning environmental sustainability, as the indexes indicate the absence or low effectiveness of the applied policies. Major adjustments must be made in all countries in air, ground and tourist infrastructure with the exception of Bahrain. Also the natural and cultural resources are undervalued although the majority of the Arab countries are full of natural resources and cultural heritage that need to be discovered and well- maintained. Concerning T\&T economic indicators such as tourist arrival, tourist receipts, employment and T\&T share in the GDP of the chosen countries in the MENA region (Table 3), Saudi Arabia receives most tourist arrivals $(17,994,225)$ followed by Morocco and Egypt successively. Bahrain has the lowest tourist arrival figures and also tourist receipts. Saudi Arabia also ranks first among the chosen candidates concerning tourist receipts followed by Lebanon. Lebanon is one of the countries which receive the lowest tourist arrivals; nevertheless it ranks second concerning tourist receipts. Egypt ranks first related to T\&T industry contribution to employment supplying 1,110,550 jobs followed by Morocco (731,525 jobs). Lebanon ranks first concerning T\&T share in the GDP with $8.1 \%$ followed by Morocco $(7.7 \%)$. This share indicates that the T\&T plays a vital role in the economies of these countries; therefore more attention should be given to the sector to sustain growth (T\&T report, 2017).

Table 3: T\&T Key indicators

\begin{tabular}{|l|c|c|c|c|c|}
\hline & T\&T Rank & Tourist Arrivals & Tourist Receipts & $\begin{array}{c}\text { T\&T industry } \\
\text { Employment }\end{array}$ & $\begin{array}{c}\text { T\&T industry } \\
\% \text { of GDP }\end{array}$ \\
\hline Egypt & 74 & $9,139,104$ & US \$ 6,065.1 million & $1,110,550$ jobs & \\
\hline Bahrain & 60 & $1,200,000$ & US \$ 1,197.0 million & 31,738 jobs & $4.3 \%$ \\
\hline Saudi Arabia & 63 & $\underline{17,994,225}$ & US \$ 10,129.7 million & 727,579 jobs & $2.5 \%$ \\
\hline Morocco & 65 & $\underline{10,176,762}$ & US \$ 5,852.8 million & 731,525 jobs & $7.7 \%$ \\
\hline Oman & 66 & $1,897,000$ & US \$ 1,539.7 million & 53,251 jobs & $2.5 \%$ \\
\hline Jordan & 75 & $3,761,072$ & US \$ 4,064.9 million & 71,882 jobs & $5.6 \%$ \\
\hline Tunisia & 87 & $5,359,309$ & US \$ 1,380.8 million & 185,290 jobs & $5.8 \%$ \\
\hline Lebanon & 96 & $1,517,927$ & US \$ 6,857.3 million & 120,894 jobs & $8.1 \%$ \\
\hline
\end{tabular}

Sources: World Tourism Organization (UNWTO) and World Travel and Tourism Council (WTTC)

\section{Results of Pearson `s Correlation}

Pearson's correlation coefficient has been used to perform the measurements and test relationships between variables. The analysis was conducted between the indexes of the pillars of the T\&T competitiveness report and the overall competitiveness index (TTCI) of the chosen countries (Table 4). 
International Journal of Heritage, Tourism and Hospitality Vol. (13), No. (1), March, 2019

By: Faculty of Tourism and Hotels, Fayoum University

Table 4:Pearson's r of TTCI and T\&T sub indexes

\begin{tabular}{|l|r|}
\hline & Pearson's $r$ \\
\hline Business environment & $\underline{\underline{0.918506}}$ \\
\hline Safety and security & $\underline{\underline{0.679551}}$ \\
\hline Health and hygiene & $\underline{\underline{0.625305}}$ \\
\hline Human resource and labor market & $\underline{\underline{0.825967}}$ \\
\hline ICT readiness & $\underline{\underline{0.840331}}$ \\
\hline Prioritization of T\&T & $\underline{\underline{0.743619}}$ \\
\hline International Openness & $\underline{\underline{0.562638}}$ \\
\hline Price Competitiveness & -0.35264 \\
\hline Environmental Sustainability & $\underline{\underline{0.805105}}$ \\
\hline Air Transport Infrastructure & $\underline{\underline{0.888215}}$ \\
\hline Ground and port infrastructure & $\underline{\underline{0.827815}}$ \\
\hline Tourist Service Infrastructure & $\underline{\underline{0.815364}}$ \\
\hline Natural Resources & 0.304755 \\
\hline Cultural Resources \& Business Travel & 0.240361 \\
\hline
\end{tabular}

Figure 2: Scatter plot TTC and business environment

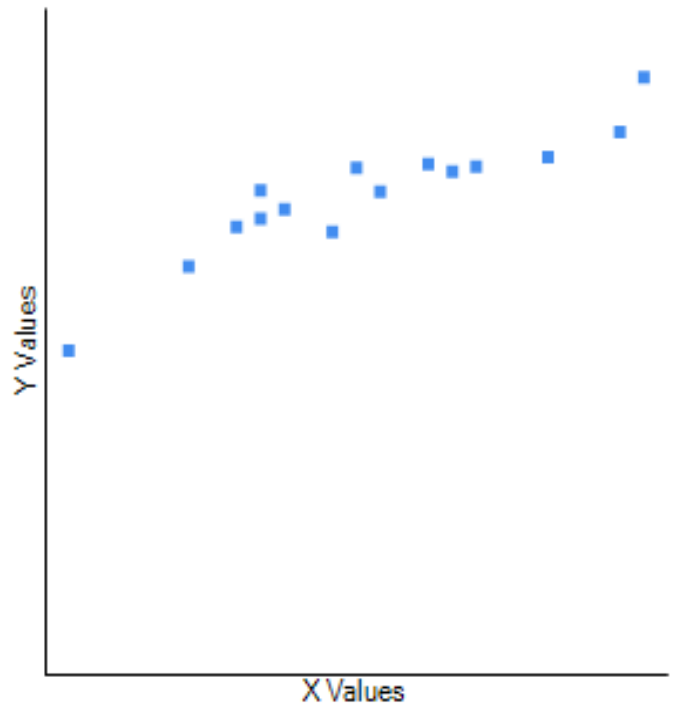

Pearson's correlation analysis of the variable overall T\&T competitiveness index (TTCI)of the chosen countries and the indexes of the pillars showed a strong positive relationship between the variable "Business environment" $(r=0.92)($ Fig.2), as well as a strong association between the TTCI and the pillar "Safety and Security" $(\mathrm{r}=0.68)$, "Health and hygiene" (r=0.63), "Human resource and labor market" ( $\mathrm{r}=0.83)$ and "ICT readiness" $(\mathrm{r}=0.84)$. The results are significant at $\mathrm{p}<0.05$.

Pearson's Correlation analysis also showed a strong positive relationship between TTCI and "Environmental Sustainability" ( $r=0.81)$, "Air Transport Infrastructure" $(r=0.89)$, "Ground and port infrastructure" ( $\mathrm{r}=0.83)$, "Tourist Service Infrastructure" $(\mathrm{r}=0.82)$ and "Prioritization of T\&T" $(r=0.74)$ and a positive moderate relationship with "International Openness" $(r=0.56)$. Other variables like "Natural and cultural resources" showed a weak relationship with the variable TTCI with $r=0.304$ and 0.240 respectively. The index of pillar "Price competiveness" indicated a weak negative relationship with the TTCI ( $\mathrm{r}=-0.352)$.

There is also a strong positive relationship between variables "Business environment" with "Air infrastructure", "Ground infrastructure" and "Tourist service infrastructure" ( $r=0.8177,0.8203$, 0.6860 respectively). Also the analysis indicated a strong positive relationship between variable "ICT readiness" and "Air infrastructure", "Ground infrastructure" and "Tourist service infrastructure" ( $\mathrm{r}=0.7417,0.7352,0.8461$ successively). The results also showed a strong positive relationship between variable "Prioritization of T\&T" and variable "International openness" $(\mathrm{r}=0.5491)$. This indicates that there is a direct affiliation between the enhancement of the T\&T sector and the facilitation of visa requirements and engagement in "bilateral Air Service and trade Agreements".

The analysis also showed that the overall T\&T index (TTCI) has a stronger relationship with pillar "Business environment", "Air Transport Infrastructure" and "ICT readiness" successively, which are influencing more than others the overall T\&T competitiveness index. These results have important implications for tourism destinations who are seeking to enhance their competitiveness index. Efforts should be directed mainly towards areas "Business environment", 
"Air transport infrastructure" and "ICT readiness" to boost the TTCI. Other variables like "Health and hygiene", "Safety and security" and "International openness" are also important but to a lesser extent.

\section{Egypt's PESTEL Analysis}

PESTEL stands for "Political, Economic, Social, Technological, Environmental and Legal" and is used for strategic planning, marketing, product development, decision making and production of research reports. PESTEL analysis analyzes factors that influence organizations on a macrolevel. Political factors address the stability of the nation, political issues, foreign trade relations, corruption and bureaucracy. Economic factors include GDP trends, interest rates, inflation, taxations and unemployment. Socio-cultural factors concentrate on demographic indicators, income distribution, lifestyle trends, work ethics, consumerism, and educational level. Technological factors include government spending on research, government efforts toward technological achievements, new technological discoveries and the level of technology transfer. Ecological factors address legislations related to environmental preservation, waste management policies and energy consumption. Legalfactors include state monopoly regulations, employment laws, health and safety and consumer protection laws (Johnson and Scholes, 2002).

In order to analyze the position of Egypt, a PESTEL analysis was conducted in order to illustrate the strengths and weaknesses of the country and draw conclusions based on the analysis. These conclusions could be used by decision makers to accentuate the strengths and identify weaknesses to resolve them.

\section{Political factors}

Strengths

- The development of tourism in Egypt is supported by state bodies and governments (rank $37^{\text {th }}$, T\&T report 2017)

- Good relationships between Egypt and other countries in the region.

- Trade relations with countries worldwide.

- A member of several international organizations and forums.

- Crossroads between continents with the Suez Canal connecting Africa with Asia.

Weaknesses

- Regional political instabilities after the Arab Spring in 2011 (Safety and Security rank 130th, T\&T report 2017.)

- Some dispersed incidents of terrorism attacks.

\section{Economic factors}

Strengths

- Diversified economy and self sustainability in many economic sectors.

- A stable financial system and institutions.

- A downturn in the economy after 2011 but the country is growing steadily after the elections.

- High governmental prioritization of T\&T sector (Prioritization of Travel \& Tourism rank 37th,T\&T report 2017)

- High government spending on T\&T sector (T\&T government expenditure rank 22nd, T\&T report 2017)

- Opportunities for intra-regional Arab tourism - similar language \& traditions 
- Joint investments between public and private sectors.

- Established tourism infrastructure (e.g. presence of world-renowned hotel chains and resorts in Egypt).

- (Quality of tourism infrastructure rank 39th, T\&T report 2017)

- Tourism is one of the fastest growing sectors.

- High service quality in tourism.

- High price competitiveness (Price competitiveness rank 2nd, T\&T report 2017).

- Governmental efforts to support entrepreneurship and SMTEs to overcome unemployment problems.

- Broad tourism promotional activities (Country brand strategy rating rank 60th,T\&T report 2017)

- Qualified workforce in the tourism field because of the presence of tourism educational institutions and training)

- Developed MICE infrastructure, sports activities and shopping facilities (Number of large stadiums rank22nd, T\&T report 2017)

- The existence of unexploited natural and cultural resources

- Emerging tourist markets (e.g. China, India)

- A stable national airline (Egypt Air) which has routes to many destinations in the world (Available seat kilometers, international rank 33rd, T\&T report 2017)

- The availability of tourism research data (Timeliness of providing monthly/quarterly T\&T data rank 28th, T\&T report 2017).

- Diverse tourism products (cultural, religious, recreational, ecological....etc.)

Weaknesses

- Leakage of some tourism revenues.

- More investment incentives for the tourism sector should be initiated.

- Insufficient tourism promotion.

- High CPI(Consumer Price Index) and inflation rates have to be closely monitored

- Seasonality of the tourism product in some areas.

- The SMTEs should be effectively supported by the government

- More attention should be given to establishing a disaster management system to restrain the effects of disasters.

\section{Socio-cultural factors of destination}

Strengths

- Consumer buying patterns of international tourists are pointing to sustainable and responsible tourism which suits the potentials in Egypt.

- Egypt can be branded and positioned as an authentic tourism destination with distinctive ethnic culture, traditions, customs and cuisine.

- Egypt mixes between modern and authentic lifestyle

- Awareness about the benefits of tourism among the Egyptian society is embedded.

\section{Weaknesses}

- Community engagement in the tourism field should be enforced

- More emphasize should be given to destination management systems (DMS) with close collaboration with stakeholders.

- The threat of commercialization of culture through intensive tourism activity may occur. 
- Efforts should be done to enlist more natural and cultural resources in the Tangible and Intangible World Heritage Site list.

\section{Technological factors of destination}

Strengths

- Developed communication services like cell phones (Mobile network coverage rank 46th,T\&T report 2017)

- Online booking facilities of the majority of accommodation types especially international hotel chains

- The digitalization of everyday life services (e.g. e-government, e-banking).

- Investments in a variety of smart services like augmented and virtual reality, QR codes in tourist attractions.

Weaknesses

- Further improvements in the infrastructure like local transport, roads...etc (Quality of roads rank 105th, T\&T report 2017)

\section{Ecological factors of destination}

Strengths

- A variety of eco-tourism opportunities are untapped and the presence of several protected areas.

- Pleasant climate all year round.

- A clean energy strategy to reduce carbon emissions was initiated by the government.

- Governmental entities monitor environmental issues.

- Initiatives of spreading environmental awareness to ensure sustainability.

- Waste management policies.

- EIA (Environmental Impact Assessment) are included in the feasibility studies of all project.

- Many tourism institutions are adopting green strategies for waste management, marketing and operational functions and many hotels are labeled "Green".

\section{Weaknesses}

- More efforts should be given to sustainability measures in tourist attractions with consideration to carrying capacity principles.

- Industrial waste management should be closely monitored.

- Environmental laws should be enforced (Stringency of environmental regulations rank 134th, Enforcement of environmental regulations rank 135th, T\&T report 2017)

- More efforts in spreading awareness about responsible planning as an most important prerequisites for long-term sustainable development of tourism.

- Spatial planning and proper use of space should be present to balance between accommodation, transport, communications and other services.

- Sewage systems, power generation and irrigation systems should be planned in an eco-friendly way (e. g. solar power).

- Sustainable development of tourism areas should be closely monitored.

\section{Legal factors of destination}

Strengths

- There is stable legislative structure in Egypt. 
- Tourism legislations and laws for starting a business and renewal of licenses are present.

- Government initiatives to ease the regulations to start a business are frequently studied.

- An investment guide for industrial sectors.

- Distinctive laws for hiring and firing labor force.

- Health and safety regulations are present.

- Money laundering regulations exist.

- Presence of tax regulations.

\section{Weaknesses}

- Environmental laws have to be strictly monitored

- Labor laws are present but should be closely monitored.

- Competitive and anti-monopoly laws exist but should be effectively enforced.

- The corruption index of Egypt must be enhanced.

\section{Results and Discussion}

The research aimed at assessing the position of Egypt among its regional tourism competitors in the MENA region. As the concept of competitiveness was addressed by many authors from different angles, this research chose some areas of resemblance to choose the candidates that were approached as Egypt's competitors. The model of Zhang and Jensen (2007) identified price competitiveness, natural resources, geography, climate and cultural heritage to pinpoint competitive destinations. The destinations Jordan, Bahrain, Saudi Arabia, Oman, Lebanon, Tunisia and Morocco were chosen as Egypt's potential competitors based on geographical location and also the resemblance in areas previously discussed by Zhang and Jensen (2007). The analysis showed that these countries were close to Egypt when the TTCI is in question, ranging from rank $60^{\text {th }}$ for Bahrain till rank 74th for Egypt with a gap in ranking for Lebanon $\left(96^{\text {th }}\right)$ and Tunisia $\left(87^{\text {th }}\right)$.

Some countries gained a high ranking in some areas preceding hereby by far their competitors. For example, Oman ranks first among its competitors concerning "Safety and security" with index (5.6) while Lebanon compared to it has a low index (3.6) because of its political instabilities. On the other hand, Lebanon surpasses Oman in "Health and Hygiene" and "Prioritization of T\&T". This shows that every country should focus on its weaknesses and try to improve these shortcomings by effective policies to guarantee stable tourism growth rates. It can also be noticed that almost all of the chosen Arab countries share inadequacies in some areas like managing natural and cultural resources and developing air infrastructure.

Bahrain ranks first among the chosen countries concerning adequacy of "business environment" followed by Saudi Arabia. Lebanon and Saudi Arabia precede the rest of the countries in "Health and Hygiene". Concerning the index of "Labor market and human resources" and "ICT readiness", Bahrain and Saudi Arabia precede other competitors. Jordan followed by Egypt and Morocco have surpassed their competitive destinations in "T\&T prioritization". The area of "International openness" is a drawback in almost all of the chosen countries. Egypt ranks first among the chosen countries in the area of "Price competitiveness" ranking $\left(2^{\text {nd }}\right)$ worldwide followed by Saudi Arabia. Almost all the chosen countries have downsides concerning environmental sustainability. This can be due to the absence of environmental laws or the lack of monitoring activities by governmental institutions. Improvements must be made for all countries in "Air, ground and tourist infrastructure" with the exception of Bahrain. Also the natural and 
cultural resources have a low value preposition even though the Arab region is full of natural resources and cultural heritage as it was the origin for several civilizations.

There are considerable deviations in country performance across the region compared to the year 2015. Bahrain and Morocco have improved their security notably, whereas Saudi Arabia has recorded the largest regional progress in health and hygiene. Some countries such as Egypt, Oman, and Saudi Arabia have promoted their cultural resources more than the regional average, while Bahrain and Tunisia have focused on improving international openness compared to the other competitive countries in the area.

The T\&T key indicators of the chosen countries in the Middle East and North Africa showed that Saudi Arabia received most tourist arrivals $(17,994,225)$ compared to other countries in the region followed by Morocco and Egypt successively. It can be also noted, that although Bahrain ranks best among the chosen countries $\left(60^{\text {th }}\right)$ in the TTCI, it received the lowest tourist arrivals and tourist receipts among the chosen countries. Saudi Arabia ranks first concerning tourist receipts followed by Lebanon. It is worth to mention that although Lebanon is one of the countries which receives the lowest tourist arrivals, it ranks second concerning tourist receipts. Egypt ranks first when the provision of employment opportunities is in question contributing with 1,110,550 jobs followed by Morocco (731,525 jobs). Lebanon ranks first regarding T\&T share of GDP followed by Morocco.

In order to answer the first research question, correlation analysis was conducted to examine the direction and level of strength of the relationship between the variable TTCI and other pillars. The examination showed that all the pillars have a strong relationship with TTCI except the variables "natural and cultural resources" which have a weak relationship and "price competitiveness" which showed a negative a negative weak relationship with variable TTCI.

The results also indicated that the overall $\mathrm{T} \& \mathrm{~T}$ index showed a stronger relationship with "Business environment" followed by "Air Transport Infrastructure" followed by "ICT readiness". These results could be used by decision makers in tourism destinations seeking to enhance the T\&T competitiveness of their countries. Devoted efforts should be directed to inadequacies deterring the tourism system from achieving the intended growth. Problems with political instabilities must have the utmost attention because they constitute major obstacles to tourism growth. Also, deficiencies in the systems concerned with "Business environments" or regulatory framework should be given all the attention. All countries must give the tourism infrastructure great priority especially air infrastructure because it is one of the most important factors that shape the direction of the tourism flow worldwide.

Hereby the first research question was answered indicating that certain pillars are more important than others in affecting the TTCI.

The research attempted to answer the second research question by conducting a PESTEL analysis for Egypt. The analysis showed that Egypt has great potentials to increase its competitiveness ranking. On the political level Egypt has good diplomatic, trade relations with many countries worldwide and a strategic geographic location. Economically, it has a stable financial system, diverse economy and diversified tourism product substantiated by solid tourism infrastructure. The country also offers a high service quality, a qualified workforce in the tourism sector, unexploited natural and cultural tourism resources and the availability of tourism research data. All these factors reinforce Egypt's position for tourism expansion.

On the socio-cultural level, consumer patterns show a tendency towards responsible tourism which suits the potentials of Egypt which has a number of already developed and untapped 
ecological resources. Egypt has a distinctive ethnic culture, traditions, customs and cuisine and at the same time it mixes between modern and authentic lifestyle.

Technological approaches have been widely taken by the government to digitalize the majority of services of daily life. Also, developed communication services like broadband and cell phones are developing rapidly in Egypt. Online booking facilities and investments in a variety of smart services like augmented and virtual reality, QR codes in tourist attractions are gaining momentum.

Concerning ecological factors, Egypt is taking serious initiatives to obtain a clean environment by adopting energy strategies to reduce carbon emissions, the government is spreading environmental awareness to ensure sustainability and many tourism institutions are adopting green strategies for waste management, marketing and operational functions.

On the legislative level, Egypt has a stable legislative structure and institutions. The government has taken major steps to ease the regulations to start a business and legislations in all areas are present.

The examination showed some weaknesses in some areas like political instabilities, leakage of tourism revenues, insufficient tourism promotion, high CPI and inflation rates and seasonality of the tourism product. Furthermore, Egypt's government should support SMTEs which are the backbone of the tourism sector and it should build a disaster management system to face any disasters that may arise. Community engagement in the tourism field should be enforced. More focus should be given to destination management systems (DMS) with close collaboration with stakeholders. Egypt should encourage reviving its cultural heritage which is threatened by commercialization. It should also make efforts to add more natural and cultural resources in the World Heritage Site list. More improvements should be done in the area of ground and air infrastructure. In addition to that, law enforcement in all areas should be given great attention and also the corruption index should be improved.

Porter (1980) formulated three strategies to outperform competitors, namely cost leadership, differentiation and niche strategy. Cost leadership requires an "aggressive" price policy and a well- established infrastructure and organization capabilities. To adopt a differentiation strategy, the destination needsto be positioned as unique in relation to some attributes or resources that are widely valued. This can be achieved by branding activities. Concentration strategies could be achieved by focusing on niche markets through embarking upon one or more markets.

It is recommended that Egypt adopts one or more of these strategies to nurture its competitive position, enhance its performance and create an added value of its T\&T sector.

Based on the analysis, some deficiencies in some areas in Egypt could be detected. Nevertheless, the opportunities for tourism growth are major. The government should support the sector financially and legislatively in order to assure the expansion and development of the T\&T sector. Hereby the second research question was answered.

\section{Future Research}

This research can be considered as a comparative study seeking to examine the position of Egypt versus regional competitive countries. The research was limited to a purposive sample focusing on certain countries that have similarities with Egypt in areas like language, cultural heritage, geography and prices. Future research could be directed to a broader scale including indirect competitors with high T\&T competitiveness rankings whose policies and competitiveness indicators may be taken as a benchmark for Egypt to enhance its tourism sector. 


\section{References}

Boo, S., Busser, J. and Baloglu, S. (2009). A model of customer-based brand equity and its application to multiple destinations. Tourism Management, No. 30, pp. 219-231.

Buhalis, D. (2000). Marketing the Competitive Destination of the Future. Tourism Management, Vol. 21, pp.1-27.

Claver-Cortes, E., Molina-Azarin, J.F. and Pereira-Moliner, J. (2007). Competitiveness in mass tourism. Annals of Tourism Research, Vol. 34, No. 3, pp. 727-745.

Cracolici, M.F. and Nijkamp, P. (2008). The attractiveness and competitiveness of tourist destinations: A study of Southern Italian regions. Tourism Management, No. 30, pp. 336- 344.

Craigwell, R. (2007). Tourism competitiveness in Small Island Developing States. Research Paper, No. 19, UNU World Institute for Development Economics Research, Helsinki, Finland.

Crouch, J. and Ritchie, B. (2003). The Competitive Destination: A Sustainable Tourism Perspective. Wallingford, UK, Cabi Publishing.

De Keyser, R. and Vanhove, N. (1994). The competitive situation of tourism in the Caribbean area-methodological approach. The Tourist Review, Vol.49 (3), pp.19-22.

Dupeyras, A. and MacCallum, N. (2013). Indicators for Measuring Competitiveness in Tourism: A GuidanceDocument", OECD Tourism Papers, 2013/02, OECD Publishing.

Dwyer, L. and Kim, C. (2003). Destination competitiveness: Determinants and indicators. Current Issues in Tourism, Vol. 6, pp. 369-414.

Ejarque, J., 2005. Destinosturisticos de exito. Diseno, creacion, gestion. Marketing, Madrid, Edicionesn Piramide.

Hassan, S.S. (2000). Determinants of market competitiveness in an environmentally sustainable tourism industry. Journal of Travel Research, Vol. 38, pp. 239-245.

Johnson, G. and Scholes, K. (2002). Exploring Corporate Strategy, text and cases, Prentice Hall, Hemel Hempstead.

Kotler, Ph., Bowen, J.T. and Markens, J.C.(2006). Marketing for Hospitality and Tourism, New Jersey, Pearson Prentice Hall International Edition.

Kozak, M. and Rimmington, M. (1999). Measuring tourist destination competitiveness: Conceptual considerations and empirical findings. International Journal of Hospitality Management, Vol.18, pp. 273-283.

Mihalič, T. (2000). Environmental management of a tourist destination - A factor of tourism competitiveness. Tourism Management, No. 21, pp. 65-78.

Omerzel, D. (2006). Competitiveness of Slovenia as a Tourist Destination. Managing Global Transitions, Vol. (4), No. (2),pp.167-189.

Porter, M. (1980). The competitive strategy: Techniques for analyzing industries and competitors. New York: The Free Press.

Royo-Vela, M. (2009). Rural-cultural excursion conceptualization: A local tourism, marketing management model based on tourist destination image measurement. Tourism Management, No. 30, pp. 419-428.

T\&T report (2017), World Economic Forum. The travel \& tourism competitiveness report 2017:Paving the way for a more sustainable and inclusive future. Geneva, Switzerland.

Zhang, J. and Jensen, C. (2007). Comparative advantage Explaining Tourism Flows. Annals of Tourism Research, Vol. 34, No. 1, pp. 223-243. 